\title{
Puebla, Pedro Arrupe e a Análise Marxista: Discernimento em tempos da Guerra Fria
}

\author{
Puebla, Pedro Arrupe and Marxist Analysis: \\ Cold War Discernment
}

Luís Corrêa Lima

\section{Resumo}

A Terceira Conferência Geral do Conselho Episcopal Latino-americano, reuniu-se em Puebla (México), em 1979, com o tema: "Evangelização no presente e no futuro da América Latina". Prosseguiu o caminho da Conferência anterior, de Medellín, reiterando a opção pelos pobres e pela libertação, e a importância das Comunidades Eclesiais de Base (CEBs). Entre as questões tratadas por Puebla estão as ideologias, especialmente o liberalismo capitalista, o coletivismo marxista e a doutrina de segurança nacional. Eram tempos da Guerra Fria, de disputas estratégicas e conflitos indiretos entre Estados Unidos e União Soviética, e suas zonas de influência, abrangendo a América Latina. Uma das interrogações daquela época é se um cristão pode ser marxista e adotar sua análise para a compreensão da realidade social. Os provinciais jesuítas colocaram esta questão ao seu superior geral, padre Pedro Arrupe, que com base em ampla pesquisa e nas conclusões de Puebla escreveu uma carta sobre análise marxista. Esta carta revela uma lúcida percepção dos sinais dos tempos e um profetismo na linha do Concílio Vaticano II, com elementos bastante válidos também para os tempos atuais.

Palavras-chave: CELAM. Ideologia. Profetismo.

\section{Abstract}

The Third General Conference of the Latin American Episcopal Council 
met in Puebla (Mexico) in 1979 with the theme: "Evangelization in the present and future of Latin America". It continued the path of the previous Conference in Medellin, reiterating the option for the poor and the liberation, and the importance of the Ecclesial Base Communities (CEBs). Among the issues addressed by Puebla are ideologies, especially capitalist liberalism, Marxist collectivism, and the doctrine of national security. These were times of the Cold War, of strategic disputes and indirect conflicts between the United States and the Soviet Union, and its zones of influence, covering Latin America. One of the questions of that time is whether a Christian can be Marxist and adopt his analysis for the understanding of social reality. The provincial Jesuits put this question to their general superior, Father Pedro Arrupe, who based on extensive research and the conclusions of Puebla wrote a letter on Marxist analysis. This letter reveals a clear perception of the signs of the times and a prophetism in the line of the Second Vatican Council, with elements valid for the present times.

Keywords: CELAM. Ideology. Prophetism.

\section{Introdução}

A Igreja Católica na América Latina e do Caribe criou um organismo colegiado dos bispos em nível continental, o Conselho Episcopal Latinoamericano (CELAM), para refletir sobre sua missão evangelizadora. Este Conselho tem encontros gerais periódicos em intervalos pouco maiores que uma década. A origem deste colegiado de bispos remonta a 1899, quanto por iniciativa do bispo chileno Carlos Casanueva, o papa Leão XIII convocou o Primeiro Concílio Plenário Latino-americano em Roma, por ocasião do quarto centenário da chegada dos colonos espanhóis à América. Este Concílio teve a presença de treze arcebispos e quarenta bispos. ${ }^{1}$ Mais de meio século depois, em 1955, realizou-se no Rio de Janeiro a Primeira Conferência Geral do Episcopado Latino-americano. No ano seguinte surgiu o CELAM, institucionalizando-se como um corpo eclesial-episcopal por iniciativa de alguns bispos e pelo impulso das instâncias romanas. Com o Concílio Vaticano II e a valorização da colegialidade, esta instituição eclesial latino-americana

\footnotetext{
${ }^{1}$ ARENAS, S., Conferências do Conselho Episcopal latino-americano (CELAM).
} 
adquiriu progressivamente mais consciência da cooperação episcopal mútua e suas repercussões pastorais positivas.

As Conferências Gerais do Episcopado, que são os encontros amplos periódicos, procuram conhecer e estudar a realidade, refletindo-a à luz da fé, buscando encontrar horizontes e caminhos para o anúncio de Jesus Cristo aos homens e mulheres do Continente. Caracterizam-se pela reflexão pastoral. Seus debates não entram os assuntos dogmáticos, ligados às verdades da fé. As reflexões pastorais têm sua origem na análise profunda da realidade social, política, econômica, cultural, religiosa e eclesial. Contam com as contribuições das ciências através de assessores e peritos que fornecem elementos para uma análise crítica, precisa e atenta à realidade.

O papa tem grande influência nas Conferências Gerais. É ele quem as convoca, nomeia seus presidentes, envia representantes da Cúria Romana e aprova (ou não) a participação dos delegados eleitos pelos bispos em nível local. Os trabalhos destas Conferências são orientados pelo discurso inaugural do papa, que tem um papel importante nas discussões. O produto final destas Conferências é um documento votado pelos bispos participantes, que depois de aprovado por eles é submetido à aprovação de Roma para publicação. $\mathrm{O}$ documento final é obra exclusiva dos membros da Conferência, diferente do Sínodo dos Bispos, cujo resultado frequentemente é uma exortação póssinodal assinada exclusivamente pelo papa. ${ }^{2}$

A Segunda Conferência Geral do Episcopado ocorreu em Medellín (Colômbia), em 1968. É considerada uma grande recepção continental e criativa do Concílio Vaticano II. Cerca de 750 bispos reuniram-se ao redor do tema "A Igreja na atual transformação da América Latina à luz do Concílio". Junto à recepção conciliar, os bispos desejaram ter uma compreensão adequada da situação social a partir da qual surgiram os temas de reestruturação eclesial, comunidades de base e um novo método teológico, com fundamento na preocupação com os pobres e pela libertação. ${ }^{3}$

A Terceira Conferência Geral do Episcopado teve lugar em Puebla (México), em 1979. A ideia de convocá-la surge no décimo aniversário de Medellín, em meio à extraordinária recepção na Igreja latino-americana da carta de Paulo VI sobre a evangelização, Evangelii Nuntiandi (1975). Entre Medellín e Puebla, há um amadurecimento que determinou a proposta

\footnotetext{
${ }^{2}$ SOUZA, N., Do Rio de Janeiro (1955) à Aparecida (2007), p. 128.

${ }^{3} \mathrm{DM}$.
} 
temática: "Evangelização no presente e no futuro da América Latina". O Continente vivia uma das épocas sociais mais complexas da história recente, com regimes ditatoriais e repressivos, violência institucionalizada, bloqueios, desmantelamento de revoluções, abstenções eleitorais, fronteiras de apoio político e militar de potências estrangeiras, e outros problemas.

Os resultados no documento final foram notáveis, significando um passo adiante em relação ao encontro de Medellín. A recuperação da consciência histórica, na exigência de uma certa compreensão da missão, determinou a maneira pela qual a evangelização da cultura e da piedade popular foi compreendida. Proclamou-se a opção preferencial da Igreja pelos pobres e oprimidos, pelos jovens, pela dignidade das pessoas e pela libertação integral. A Igreja Católica demonstrou capacidade de alcançar uma autoconsciência histórica totalizante de sua missão, fazendo uma leitura contextual própria da realidade do povo fiel, das alegrias e esperanças dos fiéis latino-americanos. Em Puebla, confirmam-se estatutariamente as Comunidades Eclesiais de Base como caminho de construção de uma Igreja de comunhão e participação.

As conferências do episcopado latino-americano sem dúvida marcaram a agenda do catolicismo no Continente, dando-lhe novas linguagens pastorais, de modo que os fiéis latino-americanos pudessem se relacionar com o mundo dispondo de mediações mais próximas de sua própria realidade. As primeiras assembleias deram certa legitimidade aos movimentos sociais cristãos emergentes ou consolidados. ${ }^{4}$

O contexto mais amplo das conferências de Medellín e Puebla é marcado pela chamada Guerra Fria, isto é, um período de disputas estratégicas e conflitos indiretos entre Estados Unidos e União Soviética, desde o término da Segunda Guerra Mundial (1945) até o fim da União Soviética (1991). Trata-se de um amplo conflito político, econômico, militar, tecnológico e ideológico entre as duas nações e suas zonas de influência. É chamada fria pela ausência de guerra direta entre estas superpotências, dada a impossibilidade de vitória em um confronto nuclear.

A Guerra Fria envolveu mais fortemente a América Latina a partir dos anos 60, com a aliança entre Cuba e a União Soviética, e com a implementação de ditaduras militares em diversos países em nome do anticomunismo. Eram tempos do guerrilheiro itinerante Che Guevara e seu martírio pela causa da Revolução comunista, bem como do sacerdote guerrilheiro colombiano Camilo

\footnotetext{
${ }^{4}$ ARENAS, S., Conferências do Conselho Episcopal.
} 
Torres. Muitos cristãos e não cristãos acreditavam na marcha inexorável da sociedade rumo ao comunismo, à sociedade sem classes onde o Estado por fim iria desaparecer.

A alta hierarquia da Igreja Católica sempre se posicionou contra o marxismo e o comunismo, desde o seu surgimento. ${ }^{5} \mathrm{Na}$ obra principal de Karl Marx, $O$ Capital, ${ }^{6}$ expõe-se a sua análise da sociedade. Esta vem a ser a decomposição teórica da sociedade atual, capitalista, e a identificação dos elementos que geram e sustentam tal tipo de sociedade. O capital, ou a posse particular dos meios de produção, seria a peça responsável pela história da sociedade e o seu atual estado. Para Marx, os proprietários exploram os trabalhadores assalariados, comprando-lhes o trabalho por salário inferior ao seu valor. A mercadoria produzida pelos operários é vendida por um preço muito mais elevado do que o preço do trabalho e dos demais custos de produção, possibilitando o lucro dos proprietários. Esta diferença, correspondente a horas de trabalho a mais, é chamada mais valia.

Assim a classe capitalista se opõe ao proletariado e é o seu explorador coletivo. A procura constante de mais valia acarreta a crescente exploração do trabalhador: o aumento da jornada de trabalho, a exploração feroz do trabalho de mulheres e crianças e a mutilação física de milhões de operários. Estes seriam os meios utilizados pelo capital para atender à sua sede insaciável de mais valia. Todavia, em virtude da concentração e da centralização da produção capitalista, a quantidade de operários assalariados cresce sem cessar; os operários aglomeram-se em massas cada vez maiores e mais compactas nas vastas empresas capitalistas. Assim o próprio capital vai gerando, no decurso da sua evolução, a força social destinada a destruí-lo. O proletariado assim constituído fará a sua revolução, tomará o poder, estabelecerá a ditadura e expropriará os seus expropriadores.

Desta forma Marx pretendia ter descoberto a lei econômica do movimento da sociedade capitalista, e mostrado que o comunismo constitui a etapa futura e inevitável do desenvolvimento social. O advento do comunismo estaria preparado por toda a história da humanidade e pelas leis internas de evolução do próprio capitalismo. É inegável que Marx criticou o capitalismo tal como era praticado no século XIX, o capitalismo liberal no contexto industrial, que realmente foi (e é, onde ainda subsiste) desumano e anticristão. Com o passar

\footnotetext{
${ }^{5}$ LEÃO XIII, PP., Lettre Encyclique Quod Apostolici Muneris.

${ }^{6} 1^{\circ}$ volume publicado em 1867; $2^{\circ}$ volume, em $1885 ; 3^{\circ}$ volume, em 1894.
} 
do tempo, o capitalismo sofre diversas restrições por parte da legislação trabalhista e dos planos de economia dirigida de vários governos. O futuro da sociedade capitalista não ocorreu exatamente como Marx predisse, com o comunismo substituindo o regime econômico vigente na Inglaterra e no Ocidente. Mas seu pensamento ainda hoje inspira intelectuais e militantes sociais.

Na Conferência de Puebla, a oposição ao marxismo se mantém, levandose em conta também outros problemas sócio-políticos e desafios ideológicos da América Latina. A Companhia de Jesus estava profundamente envolvida nestas questões, dada a sua presença no campo do ensino e da pesquisa, nas paróquias, na educação básica e em centros sociais fomentadores de pastorais sociais. Os provinciais jesuítas latino-americanos escreveram ao superior geral, padre Pedro Arrupe, pedindo orientações sobre como proceder em relação ao marxismo. Com base nas conclusões de Puebla e em ampla consulta, o superior geral respondeu às questões, escrevendo em 1980 uma carta aos provinciais jesuítas de todo mundo sobre a análise marxista. Este texto resultou não só da reflexão pessoal do autor, mas também de meticulosas consultas a peritos sobre o assunto. Arrupe recebeu cerca de setenta relatórios e estudos de especialistas, que the permitiram elaborar um documento sólido e válido. ${ }^{7}$ Esta carta se tornou uma importante referência na relação entre a Igreja Católica e o marxismo.

\section{A Conferência de Puebla e o alerta contra as ideologias}

O papa Paulo VI foi quem convocou a Conferência de Puebla, mas antes de sua realização havia deixado um clima de muito sofrimento e decepção diante da implementação do Concílio Vaticano II. Ficou célebre a sua homilia em comemoração de seu nono ano de pontificado, na qual ele se refere à situação da Igreja afirmando: "a fumaça de Satanás entrou no templo de Deus por alguma fissura". Segundo o papa, há dúvidas, incertezas, problemas, inquietação, insatisfação e confronto. "Nós não confiamos mais na Igreja; confiamos no primeiro profeta profano que vem falar conosco de algum jornal ou de algum movimento social", para segui-lo e perguntar se ele tem a fórmula da vida real. E não sentimos que somos padrões e mestres. A dúvida entrou em nossas consciências e entrou pelas janelas que precisavam ser abertas para a

\footnotetext{
${ }^{7}$ ARRUPE, P., Análise Marxista.
} 
luz. A ciência deve ser feita para nos conduzir às verdades que não se desprendem de Deus, mas nos fazem procurá-la ainda mais e celebrá-lo com maior intensidade. No entanto, em vez disso veio a crítica e a dúvida. Infelizmente os cientistas são aqueles que com mais preocupação e mais dolorosamente curvam a cabeça. E acabam ensinando: "Eu não sei, não sabemos, não podemos saber". A escola teria se tornado uma academia de confusão e, às vezes, de contradições absurdas. O progresso é celebrado para então ser demolido com as mais estranhas e radicais revoluções, negando-se tudo o que foi conquistado, e retornando-se ao primitivo após ter exaltado o progresso do mundo moderno.

Esse estado de incerteza, prossegue Paulo VI, também reina na Igreja. Acreditava-se que depois do Concílio, um dia ensolarado viria para a história da Igreja. Em vez disso, um dia de nuvens, de tempestade, de escuridão, de busca e de incerteza chegou. "Nós pregamos o ecumenismo e nos separamos mais e mais dos outros. Nós tentamos cavar o abismo em vez de enchê-lo". Como isso aconteceu? O Papa conclui: "houve a intervenção de um poder adverso. Seu nome é o diabo, esse ser misterioso ao qual se faz alusão na Carta de São Pedro". ${ }^{8}$

Esse ambiente de suspeita contra inovações feitas em nome do Vaticano II, influenciou a eleição dos papas seguintes. Em sua primeira mensagem como pontífice, João Paulo I afirmou seu propósito de querer "conservar intacta a grande disciplina da Igreja, na vida dos sacerdotes e dos fiéis". ${ }^{9} \mathrm{E}$ João Paulo II reitera esta mensagem em seu primeiro pronunciamento: "Sob o signo da fidelidade à luz do Concílio: 'Fidelidade significa ainda a observância da grande disciplina da Igreja" ". ${ }^{10}$ Isto também teve consequências pastorais nos movimentos eclesiais. Deslocou-se a ênfase no social para a conversão pessoal sob o impacto de jogos emocionais. Movimentos espiritualizantes se disseminaram nos âmbitos da teologia, da pastoral e da vida consagrada.

A organização da Conferência de Puebla conseguiu vetar todos os teólogos da libertação, de maneira que entre os assessores não havia representantes da linha de Medellín. Tais teólogos estiveram nesta Conferência, mas fora dos muros, à disposição dos bispos. Foi desta maneira que tiveram influência e presença. ${ }^{11}$

\footnotetext{
${ }^{8}$ PAULO VI, PP., Omelia di Paolo VI.

${ }^{9}$ JOÃO PAULO I, PP. Primeira radiomensagem, p. 6.

${ }^{10}$ JOÃO PAULO II, PP. Sob o signo da fidelidade à luz do Concílio, p. 1-2.

${ }^{11}$ LIBÂNIO, J. B., Nas pegadas de Medellín, p. 6-7.
} 
A linha teológica predominante em Puebla, segundo observadores, opunha-se à Teologia da Libertação nos traços principais. A proposta de setores na direção da Conferência visava preferencialmente reverter o processo libertador, trazendo para dentro de quadro espiritual, doutrinal e menos comprometido com o engajamento político-social na perspectiva libertadora. No entanto, a temática da libertação invadiu o texto. Isto se deu em grande parte por causa dos discursos contundentes de João Paulo II ao longo de sua viagem pelo México. Enquanto os bispos reunidos em conferência deliberavam, João Paulo II percorria aquele país entrando em contato com a dura realidade social. E a partir daí fez declarações corajosas que foram incorporadas ao texto de Puebla em mais de 100 citações. ${ }^{12} \mathrm{O}$ processo de elaboração do discurso papal é diferente na abertura de uma conferência episcopal e em outros pronunciamentos em viagem pelas dioceses mexicanas, ou dirigidos a grupos específicos. Mas estes influenciaram igualmente a Conferência.

Puebla afirma que a América Latina vive em situação de opressão e dominação econômica, política e cultural, e que a Igreja se compromete com a libertação do povo oprimido. No horizonte, ergue-se o sonho da "civilização do amor", da qual falava Paulo VI, e hoje se pode falar de uma sociedade justa e solidária. Que haja entre os homens maior comunhão e participação nos bens de toda ordem que Deus nos outorgou. ${ }^{13}$

O caminho traçado pelos organizadores da Conferência visava sobretudo a produção de um texto único e articulado. As discussões faziam-se unicamente para se chegar à redação do texto final. As tensões e divergências se atenuaram. Os plenários não tinham por objetivo a discussão, mas a mera sucessão de posições, com o acúmulo de informações, sem confrontos teológicos ou pastorais. Com isto, obteve-se um texto consensual sem arestas. Para João Batista Libânio, Puebla carrega em si certa ambivalência, que corresponde ao momento histórico da Igreja naqueles anos. Já se pressentia o início da volta à disciplina em oposição à opção de avançar, arriscar, comprometer-se com a transformação da realidade eclesial e social. Mas apesar da metodologia, os assessores e os redatores principais serem de linha conservadora, causa espanto que o documento final contenha passagens altamente proféticas, ao lado de certa pobreza teológica. ${ }^{14}$

É nesta conjuntura que Puebla trata das questões da ideologia. Define

\footnotetext{
${ }^{12}$ LIBÂNIO, J. B., Nas pegadas de Medellín, as opções de Puebla.

${ }^{13}$ DP 1250-1253.

${ }^{14}$ LIBÂNIO, J. B., Nas pegadas de Medellín, p. 18.
} 
como ideologia toda concepção que ofereça uma visão sobre diversos aspectos da vida, do ponto de vista de um grupo determinado da sociedade. A ideologia manifesta as aspirações deste grupo, convida para certa solidariedade e combatividade, fundamentando sua legitimação em valores específicos. Toda ideologia é parcial, pois nenhum grupo particular pode pretender identificar suas aspirações com as de toda a sociedade. Uma ideologia é legítima se os interesses que defende também o forem, e se respeitar os direitos fundamentais dos demais grupos da nação. Neste sentido positivo, as ideologias surgem como algo necessário para a vida social, pois são mediações para a ação. ${ }^{15}$

As ideologias, porém, tendem a absolutizar os interesses que defendem, a visão que propõem e a estratégia que promovem. Eis o lado ambíguo e negativo das ideologias. Neste caso, podem se transformam em verdadeiras religiões seculares. Apresentam-se como explicação última e suficiente de tudo, construindo assim um novo ídolo, do qual se aceita o caráter totalitário e obrigatório às vezes sem se dar conta. Nesta perspectiva, não se estranha que as ideologias tentem instrumentalizar pessoas e instituições a serviço da consecução de seus fins. ${ }^{16}$

O perigo das ideologias é constituírem fenômenos vitais de dinamismo envolvente, contagioso, dotadas também de poderosa força de conquista e fervor redentor. Isso lhes confere uma "mística" especial, junto com a capacidade de penetrar diversos ambientes de modo muitas vezes irresistível. Seus lemas, expressões típicas e critérios podem marcar fácil e profundamente mesmo os que não aderem voluntariamente a seus princípios. Assim, muitos praticamente vivem e militam dentro de limites ideológicos sem se darem conta. Por isso é necessário constante revisão e vigilância. Tudo isso se aplica tanto às ideologias que legitimam quanto àquelas que contestam a situação atual. Para o devido discernimento e julgamento crítico devem os cristãos se apoiarem no rico e complexo patrimônio imaterial que é Ensinamento Social da Igreja. Este Ensinamento expressa uma visão global do homem e da humanidade, deixando-se interpelar e enriquecer pelas ideologias no que elas têm de positivo e, por sua vez, as interpela, relativiza e critica. ${ }^{17}$

Para a Conferência de Puebla, há na América Latina ideologias que exigem análise: o liberalismo capitalista, o coletivismo marxista e a doutrina de segurança nacional.

\footnotetext{
${ }^{15}$ DP 535.

${ }^{16}$ DP 536.

${ }^{17}$ DP 537-539.
} 
O liberalismo capitalista idolatra a riqueza em sua forma individual. Deve-se reconhecer a força que infunde a capacidade criadora da liberdade humana, propulsora do progresso. Contudo, considera-se o lucro como o motor essencial do progresso econômico, a concorrência como lei suprema da economia, a propriedade privada dos meios de produção como direito absoluto, sem limites ou obrigações sociais correspondentes. Os privilégios ilegítimos, derivados do direito absoluto de propriedade, causam disparidades escandalosas e uma situação de dependência e opressão, tanto nacional quanto internacional. Embora em alguns países isto historicamente se atenuou, devido à influência da legislação social e de intervenções precisas do Estado, em outros lugares ainda persiste ou mesmo retrocede a formas primitivas e de menor sensibilidade social. ${ }^{18}$

O coletivismo marxista, por seus pressupostos materialistas, conduz igualmente a uma idolatria da riqueza, mas em sua forma coletiva. Embora nascido de uma crítica positiva ao fetichismo do comércio e ao desconhecimento do valor humano do trabalho, não foi à raiz dessa idolatria que consiste na recusa do Deus de amor e justiça, o único que pode ser adorado. O que move a dialética desta ideologia é a luta de classes. Seu objetivo é a sociedade sem classes, que se alcança através de uma ditadura proletária para, enfim, estabelecer a ditadura do partido. Todas as suas experiências históricas concretas, como sistema de governo, se realizaram em regimes totalitários fechados a toda possibilidade de crítica e retificação. Alguns creem ser possível separar diversos aspectos do marxismo, em particular sua doutrina e sua análise. Mas, recordando Paulo VI, é ilusório e perigoso esquecer o nexo íntimo que os une radicalmente, aceitar os elementos da análise marxista sem reconhecer suas relações com a ideologia, entrar na dinâmica da luta de classes e de sua interpretação marxista, sem perceber o tipo de sociedade totalitária e violenta à qual tal processo conduz. ${ }^{19}$

Deve-se alertar para o risco de ideologização a que se expõe a reflexão teológica, quando se realiza a partir de uma práxis ligada à análise marxista. As consequências são a total politização da existência cristã, a dissolução da linguagem da fé na linguagem das ciências sociais e o esvaziamento da dimensão transcendental da salvação cristã. Ambas as ideologias, liberalismo capitalista e marxismo, inspiram-se em humanismos fechados a qualquer

\footnotetext{
${ }^{18}$ DP 542.

${ }^{19}$ AO 22-41.
} 
perspectiva transcendente. Uma, por seu ateísmo prático; a outra, por sua profissão sistemática de um ateísmo militante..$^{20}$

Por fim, Puebla analisa a doutrina de segurança nacional, que naqueles anos se impunha no Continente, classificando-a mais como ideologia do que como doutrina. Vincula-se a um determinado modelo econômico-político, de características elitistas e verticalistas, suprimindo a participação ampla do povo nas decisões políticas. Em certos países da América Latina, pretende justificarse até mesmo como defensora da civilização ocidental cristã. Desenvolve um sistema repressivo baseado no conceito de guerra permanente, não raramente com uma clara intensão de protagonismo geopolítico. A doutrina de segurança nacional como ideologia absoluta não condiz com a visão cristã do homem, enquanto responsável pela realização de um projeto temporal, nem com a visão cristã do Estado, enquanto administrador do bem comum. Tal doutrina impõe a tutela do povo por elites de poder, militares e políticas, conduzindo a uma acentuada desigualdade de participação nos resultados do desenvolvimento. ${ }^{21}$

Reiterando a Conferência de Medellín, Puebla afirma que o sistema liberal capitalista e a tentação do sistema marxista esgotaram na América Latina as possibilidades de transformar as estruturas econômicas. Ambos os sistemas atentam contra a dignidade da pessoa humana, pois o primeiro se baseia na primazia do capital, no seu poder e na sua utilização discriminatória em função do lucro; o segundo, embora sustente ideologicamente um humanismo, visa antes o homem coletivo e se traduz na prática em uma concentração totalitária do poder do Estado. É preciso denunciar que o Continente se encontra fechado entre essas duas opções, permanecendo dependente de um ou de outro centro de poder que canaliza sua economia. ${ }^{22}$ Eis uma clara menção à Guerra Fria, tão presente no tempo de Medellín quanto no tempo de Puebla.

\section{Pedro Arrupe e a Análise Marxista}

O superior geral dos jesuítas, padre Pedro Arrupe, exerceu esta função desde 1965 até 1981, quando se afastou por motivo de saúde. De origem espanhola, ele tinha sido por muitos anos missionário no Japão, onde chegou a atuar junto aos sobreviventes da bomba atômica em Hiroshima. Arrupe foi um dos grandes transmissores ou comunicadores do Concílio Vaticano II, do

\footnotetext{
${ }^{20}$ DP 544-546.

${ }^{21}$ DP 547.549.

${ }^{22}$ DM 1.10; DP 550.
} 
qual participou na última etapa, no outono de 1965, logo após sua eleição como superior geral.

Segundo Jean-Yves Calvez, seu influente conselheiro por mais de dez anos, Arrupe ficou claramente marcado por esta vivência, da qual extraiu uma forte vontade de retorno ao Evangelho. Imediatamente trabalhou para uma Igreja dos pobres, para uma Igreja de irmãos, para uma Igreja no mundo e para o mundo, essencialmente missionária quando a "missão" não estava mais na moda. Ele procurou comunicar isso primeiramente aos jesuítas, e também a uma multidão de religiosos e religiosas, sobre os quais teve uma notável influência. Durante todo o seu generalato, Arrupe foi presidente da conferência dos superiores gerais das congregações masculinas, dando à animação deste grupo muito de seu coração e de seu tempo, sempre na linha do Concílio. Muito contribuiu com fidelidade criativa para a sua implementação.

Uma congregação geral dos jesuítas, durante o seu generalato, definiu a missão da ordem como "serviço da fé e promoção da justiça". Arrupe estava sempre na frente, não esperava, tão logo observasse uma grande exigência evangélica. Seus colaboradores ainda se encontravam nas orientações que lhes havia comunicado no dia anterior, enquanto ele já estava mais adiante. Era muito perceptivo, curioso de tudo, capaz também de fazer uma triagem segura, com bons critérios, distinguindo as coisas importantes das sem importância. ${ }^{23}$ Este discernimento é muito próprio da espiritualidade do fundador da Companhia de Jesus, Santo Inácio de Loyola.

Após o afastamento de Arrupe em 1981, devido a uma trombose cerebral, houve uma intervenção na ordem. O papa João Paulo II nomeou um delegado pontifício para dirigir a Companhia até a eleição de um novo superior geral. A razão da intervenção foi o descontentamento crescente da Cúria Romana e do papa com os rumos da ordem no generalato de Arrupe. Foi uma época turbulenta para a ordem e sofrida para o seu superior geral afastado. Em 1983, é eleito um novo superior geral, e Arrupe faleceu anos depois, em 1991.

No final de 2018, teve início o seu processo de beatificação e canonização. O Edito do vigário geral da Diocese de Roma afirma que o servo de Deus Pedro Arrupe se consagrou à causa do Reino de Deus, professando sua fé e promovendo a inculturação no campo da evangelização. Sua vida está repleta de gestos de caridade, amor à Igreja e fidelidade ao papa. Deixou-se guiar pela sabedoria e pela liberdade que vem do Espírito Santo. Foi atento observador dos

${ }^{23}$ CALVEZ, J.-Y., A análise marxista do capitalismo não caducou, afirma o jesuíta Jean-Yves Calvez. 
"sinais dos tempos", bem como "profeta da renovação conciliar". ${ }^{24}$ Tudo isto se reflete de algum modo em sua carta sobre a análise marxista, que é datada de 8 de dezembro de 1980, solenidade da Imaculada Conceição de Maria.

A carta inicia explicando o pedido dos provinciais jesuítas, feito no ano anterior, para que o superior geral da ordem os ajudasse a aprofundar o problema da análise marxista, da qual os bispos da América Latina deram instruções importantes no documento de Puebla. Arrupe não pretende abranger todo o problema das relações entre marxismo e cristianismo, que é muito vasto e tem sido tratado em numerosos documentos eclesiais. Trata de algo mais específico e limitado: pode um cristão, incluindo um jesuíta, utilizar a análise marxista, distinguindo-a da filosofia ou ideologia marxista, e também da práxis ou da perspectiva global que essa análise implica? ${ }^{25}$

Cabe esclarecer que nem todos dão o mesmo sentido à expressão "análise marxista". É certo que a pergunta "pode um cristão utilizar a análise marxista?” é ouvida com frequência em diversas províncias. Mas nem todos os jesuítas verão refletidas suas inquietações. Há alguns, com mais frequência europeus, que por seu apostolado estão muito envolvidos em um ambiente de convicção e, às vezes, de longa tradição marxista. Há sacerdotes operários que, por inculturação e por solidariedade, sentem que não podem deixar de compartilhar pontos de vista comuns entre seus companheiros de trabalho. Só depois de se depararem com essa situação começam a fazer um discernimento à luz da fé, que consideram muito importante. Notam também que o comportamento concreto dos trabalhadores marxistas frequentemente está muito distante do marxismo teórico, e alertam contra uma supervalorização dos aspectos intelectuais do problema. ${ }^{26}$

Arrupe deseja ajudar os jesuítas que em seu ministério estão mais em contato com homens e mulheres de convicções marxistas, incluindo também os que se proclamam cristãos e cristãs marxistas. E também os que, tendo necessidade de analisar a sociedade, não podem deixar de enfrentar o problema da análise marxista. Assim pode-se trabalhar melhor na promoção da justiça que, segundo a missão da Companhia de Jesus, deve acompanhar o serviço da fé. ${ }^{27}$

\footnotetext{
${ }^{24}$ DE DONATIS, A.; TERRAMANI, M., Causa di beatificazione i canonizzazione del servo di Dio Pedro Arrupe Gondra, S.J.

${ }^{25}$ ARRUPE, P., Análise Marxista, n. 1-2.

${ }^{26}$ ARRUPE, P., Análise Marxista, n. 3-4.

${ }^{27}$ ARRUPE, P., Análise Marxista, n. 22.
} 
Em vista da análise que se faz da sociedade, pode-se aceitar certo número de pontos de vista metodológicos que mais ou menos surgem do marxismo, sob a condição de não lhes dar caráter exclusivo. Por exemplo: a atenção aos fatores econômicos, às estruturas de propriedade, aos interesses econômicos que podem mover uns ou outros; a sensibilidade à exploração de classes sociais inteiras; a atenção ao lugar da luta de classes na história de diversas sociedades, e às ideologias que podem disfarçar certos interesses e mesmo injustiças. Porém, na prática, a adoção da análise marxista raramente significa apenas adotar um método ou um enfoque. Significa geralmente aceitar também as explicações dadas por Marx sobre a realidade social de seu tempo, a fim de aplicá-las à realidade contemporânea. Portanto, em matéria de análise social não deve haver nenhum a priori. Cabem hipóteses e teorias, mas tudo deve ser verificado e nada se pode pressupor como definitivamente válido. Há casos de se adotar a análise marxista ou alguns de seus elementos como um a priori sem verificação, mas como ilustração. Com frequência se confundem abusivamente estes elementos com a opção evangélica pelos pobres, embora não derivem diretamente dela. $\mathrm{Na}$ interpretação sociológica e econômica é preciso ser muito cuidadoso em verificar os dados e esforçar-se por objetividade. $^{28}$

No núcleo do problema, coloca-se a questão: é possível aceitar o conjunto das explicações que constituem a análise social marxista, sem aderir à filosofia, à ideologia e à política marxista? Um bom número de cristãos que simpatiza com a análise marxista pensa que mesmo quando esta não implica no materialismo dialético ou no ateísmo, inclui, no entanto, o materialismo histórico e se identifica com este. Entendem que todo o social (incluindo o político, o cultural, o religioso e a consciência) é como que determinado pelo econômico. Com muita frequência o materialismo histórico é compreendido em sentido redutor: a política, a cultura e a religião perdem sua própria consistência, mostrando-se como realidades totalmente dependentes do que acontece na esfera das relações econômicas. Este modo de ver as coisas é prejudicial à fé crista, ao conceito cristão do homem e da ética. Sem dúvida, deve-se levar muito em consideração os fatores econômicos em qualquer explicação da realidade social, mas é preciso evitar a suposição de que estes fatores, nesse sentido redutor, decidem todo o resto. ${ }^{29}$

\footnotetext{
${ }^{28}$ ARRUPE, P., Análise Marxista, n. 5-6.

${ }^{29}$ ARRUPE, P., Análise Marxista, n. 7-8.
} 
O materialismo histórico carrega consigo uma crítica da religião e do cristianismo da qual a análise marxista geralmente não se liberta. Esta crítica pode abrir os olhos para os casos em que se abusa da religião para se encobrir situações sociais indefensáveis. Porém, raciocinando como se tudo dependesse em última análise das relações de produção, como se esta fosse de fato a realidade fundamental e determinante, o conteúdo da religião e do cristianismo se relativiza e se reduz. A fé em Deus Criador e em Jesus Cristo Salvador se enfraquece e aparece como algo de pouca utilidade. A gratuidade se desvanece diante da utilidade. A esperança cristã tende a se converter em algo irreal. Há quem pretenda distinguir a própria fé em Jesus Cristo, a ser guardada intacta, de suas diversas expressões doutrinais e práticas sociais, que não resistem aos ataques dessa crítica. Existe o perigo de uma crítica radical à Igreja muito além da oportuna correção fraterna, da Ecclesia semper reformanda, da Igreja sempre necessitada de reforma. Algumas vezes tendese a julgar a partir de fora, até mesmo sem reconhecê-la como o lugar da própria fé. Não é raro que a adoção da análise marxista conduza a julgamentos extremamente severos e até injustos com a Igreja. ${ }^{30}$

Mesmo que a análise social marxista não queira se distanciar do materialismo histórico em sentido pleno, sempre supõe como elemento essencial uma teoria radical do conflito e da luta de classes. É uma análise em termos de luta de classes. Mesmo reconhecendo antagonismos e luta de classes com inteiro realismo, que o cristão tem consciência de certa relação entre estes males e o pecado, deve-se evitar uma generalização indevida. Nunca foi demonstrado que toda a história humana possa se reduzir à luta, e muito menos à luta de classes no sentido estrito da palavra. A realidade social não se reduz à dialética do senhor e do escravo. Há muitos outros impulsos na história humana como a aliança, a paz e o amor. Há outras forças profundas que a inspiram. ${ }^{31}$

Este é um ponto em que a análise marxista muitas vezes não se limita à simples análise, mas torna-se uma estratégia e um programa de ação. Reconhecer a luta de classes não implica que o único modo de a eliminar seja utilizar a própria luta, estimulando o operariado contra a burguesia. Mas é raro os que adotam a análise marxista não trilharem também este caminho, assumindo o messianismo proletário da ideologia de Marx, que faz parte da

\footnotetext{
${ }^{30}$ ARRUPE, P., Análise Marxista, n. 9-10.

${ }^{31}$ ARRUPE, P., Análise Marxista, n. 11.
} 
sua filosofia antes mesmo de ele se dedicar a análises econômicas sistemáticas. Por outro lado, o cristianismo reconhece a legitimidade de certas lutas, não excluindo a revolução em situações extremas de tirania que não admitem outro remédio. Como ensina o papa Paulo VI, a insurreição revolucionária apenas se justifica em casos de "tirania evidente e prolongada", que ofende gravemente os direitos fundamentais da pessoa humana e prejudica o bem comum do país. Fora isso, a insurreição gera novas injustiças, introduz novos desequilíbrios e provoca novas ruínas. "Nunca se pode combater um mal real à custa de uma desgraça maior". ${ }^{32}$ Por isso não se pode admitir que o melhor modo de se acabar com as lutas seja a própria luta. O cristão deve tentar sempre dar prioridade a outros meios para a transformação da sociedade, recorrendo à persuasão, ao testemunho e à reconciliação, sem nunca perder a esperança da conversão. Somente em última instância se admite o recurso à luta como defesa contra a injustiça, sobretudo se esta implica em violência. Trata-se de toda uma filosofia - e, para o cristão, de uma teologia - da ação. ${ }^{33}$

Por tudo isso, embora a análise marxista não inclua necessariamente a adesão à filosofia marxista em todo seu conjunto, no entanto implica de fato em um conceito da história humana que não concorda com a visão cristã do ser humano e da sociedade, e leva a estratégias que ameaçam valores e atitudes cristãs. As consequências disto não são sempre imediatamente desastrosas, embora muitas vezes tenham sido danosas. O aspecto moral é muito importante nesta matéria: alguns cristãos que seguiram durante algum tempo a análise e a prática marxistas, confessaram ter sido induzidos a aceitar qualquer meio para chegar a seus fins. Por isto, confirma-se pelos fatos o que escreveu Paulo VI sobre ser ilusório e perigoso aceitar os elementos da análise marxista, sem reconhecer suas relações com a ideologia. ${ }^{34}$ Separar uma da outra é mais difícil do que às vezes se supõe. Daí o alerta dos bispos latinoamericanos em Puebla para o tríplice risco no âmbito da reflexão teológica: de total politização da existência cristã, de dissolução da linguagem da fé na linguagem das ciências sociais e de esvaziamento da dimensão transcendental da salvação cristã. ${ }^{35}$

Conclui-se que a adoção de alguns elementos ou da análise marxista em seu conjunto não é aceitável para os cristãos. Mesmo supondo que alguma

\footnotetext{
${ }^{32}$ PP 31.

${ }^{33}$ ARRUPE, P., Análise Marxista, n. 12.

${ }^{34}$ OA 34.

${ }^{35}$ DP 545; ARRUPE, P., Análise Marxista, n. 13-14.
} 
pessoa, utilizando um instrumental muito preciso e apurado, possa ser estritamente capaz de falar de análise marxista, sem aceitar o materialismo histórico reducionista nem a teoria e a prática da luta de classes generalizada, a maior parte dos homens, incluindo a maior parte dos jesuítas, não é capaz de fazê-lo. Existe um perigo real em crer que se pode facilmente reter a análise marxista como algo distinto da filosofia, da ideologia e da práxis política. Os próprios marxistas em geral rejeitam esta separação. Durante o período de formação dos jesuítas, não se pode apresentar esta análise como a melhor abordagem da realidade social. ${ }^{36}$

Arrupe faz um apelo aos estudiosos jesuítas para que estudem mais profundamente o problema das estruturas da propriedade (ou dos meios de produção), que está no âmago da análise marxista. Não há dúvida de que uma má distribuição da propriedade, não compensada por outros fatores, resulta ou facilita a exploração descrita por Marx e denunciada também pela Igreja. Mas não se costuma frequentemente confundir a própria instituição da propriedade com sua má distribuição? É importante pesquisar, com a ajuda da experiência, que tipo de distribuição dos direitos de propriedade, assim como de outros tipos de poder (político, sindical e outros), permite realizar um mundo mais justo e um mais pleno desenvolvimento humano nos diferentes sistemas sociais. ${ }^{37}$

Nas considerações finais da carta, há quatro indicações:

1) Apesar das reservas em relação à análise marxista, deve-se reconhecer e tentar compreender as razões de sua atração sobre tantas pessoas. Os cristãos são sensíveis ao projeto de libertar os seres humanos de dominações e opressões, à promessa de denunciar ideologias que ocultam a verdade, à proposta de suprimir as divisões sociais. Não se deve crer que isto possa ser alcançado com meios demasiadamente simples ou mesmo contrários ao fim almejado, mas também não se deve desencorajar quem busca perseverante estas metas e tem afinidade direta com a caridade, decisiva no projeto cristão. Inclusive, é preciso ser compreensivo com quem sofre na própria carne injustiças sociais revoltantes.

2) A análise marxista não é a única associada a pressupostos ideológicos ou filosóficos introduzidos sub-repticiamente. Também as análises sociais praticadas habitualmente no mundo liberal implicam uma visão materialista e individualista do mundo, oposta a valores e atitudes cristãs. Será que se

\footnotetext{
${ }^{36}$ ARRUPE, P., Análise Marxista, n. 15.

${ }^{37}$ ARRUPE, P., Análise Marxista, n. 16.
} 
dá atenção suficiente aos livros que se usam nos colégios jesuítas? Quando se emprega elementos de análise social, seja qual for sua origem, deve-se sempre criticá-los e purificá-los na linha do Evangelho, para depois escolher o que verdadeiramente ajuda a compreender e a descrever a realidade sem preconceitos.

3) Haja sempre disposição para o diálogo com os marxistas, sem recusa a colaborações concretas em favor do bem comum, conforme ensina o Concílio Vaticano II: ainda que a Igreja rejeite totalmente o ateísmo, todavia proclama sinceramente que todos os homens, crentes e não-crentes, devem contribuir para a reta construção do mundo no qual vivem em comum. Isto só é possível com um prudente e sincero diálogo. ${ }^{38}$ Mas sempre considerando o próprio papel de sacerdotes e religiosos, no caso dos jesuítas, e nunca atuando como franco-atiradores em relação à comunidade cristã e à autoridade eclesiástica. Qualquer colaboração só se dará em atividades aceitáveis para um cristão. A própria identidade deve ser preservada, pois aceitar alguns pontos de vista válidos não é deixar-se arrastar pela adoção total da análise marxista. É preciso ser em tudo consequente com a própria fé e com os princípios de ação que esta fé supõe. Que o modo de proceder mostre concretamente que a mensagem cristã traz aos homens uma riqueza muito superior à de qualquer conceito da análise marxista, por mais útil que seja.

4) Deve haver firme oposição à tentativa de se aproveitar das restrições sobre a análise marxista para desqualificar, ou condenar como marxismo ou comunismo, o compromisso com a justiça e com a causa dos pobres, a defesa que os explorados fazem de seus direitos e as reivindicações justas. Não se nota frequentemente formas de anticomunismo que não passam de meios para encobrir injustiças? Arrupe exorta: "não deixemos que se cometam abusos da crítica que fazemos ao marxismo e à análise marxista". ${ }^{39}$

O apelo final da carta é que os jesuítas se empenhem com todas as forças, dentro do âmbito da sua vocação, em favor dos pobres e contra a injustiça, mas sem permitir que a indignação obscureça a visão de fé. Que conservem sempre, mesmo em meio ao conflito, um coração cristão, com uma atitude de caridade e não de dureza. ${ }^{40}$ Isto lembra uma frase muito popular naquele tempo, atribuída ao revolucionário assassinado Che Guevara: "hay que endurecerse, pero sin perder la ternura jamás".

${ }^{38}$ GS $21 \mathrm{f}$.

${ }^{39}$ ARRUPE, P., Análise Marxista, n. 17-20.

${ }^{40}$ ARRUPE, P., Análise Marxista, n. 22. 


\section{Conclusão}

Completam-se 40 anos da Conferência de Puebla. Logo após aquele evento, escreveram-se livros e artigos, pronunciaram-se conferências, organizaram-se cursos e discussões em grupo e outras formas de estudo para assimilar os ensinamentos dos bispos. Entretanto, o tempo decantou toda essa multiplicidade de escritos, deixando-nos a água pura evangélica e de valor pastoral. A massa de conteúdos conflituosos, inseridos no documento por interesses ideológicos ou reflexos de medos, diluiu-se e se perdeu. $\mathrm{O}$ que ficou? $\mathrm{O}$ melhor da teologia latino-americana. A pastoral viva e as comunidades de base conseguiram construir o imaginário religioso social com o binômio Medellín-Puebla, como se fosse uma única opção. Ao fazêlo, associaram a ambas as conferências a opção pelos pobres, pela libertação, pelas CEBs e por uma Igreja dos pobres. Dificilmente alguém, ao ouvir falar de Medellín-Puebla, associa a tais eventos a ideia de restrição, de medo e de volta à disciplina. ${ }^{41}$

A Guerra Fria que assolava o mundo entrou em forte declínio com a queda do Muro de Berlim, em 1989, e acabou em 1991 com o fim da União Soviética. No Ocidente, muitos partidos e grupos socialistas ou comunistas tornaram-se social-democratas, ainda que alguns mantenham o mesmo nome. As metanarrativas da utopia comunista quase desapareceram, dando origem a uma época em que alguns estudiosos chamam pós-moderna. A análise marxista não tem mais o prestígio que teve e nem representa mais uma ameaça à fé cristã, de envolvê-la em uma ideologia que reduz totalmente a existência humana ao político-social, e que esvazia a dimensão transcendente da salvação.

Olhar para o tempo da Conferência de Puebla permite reconhecer o quão profético foi o alerta dos bispos contra as ideologias, especialmente a da segurança nacional, hegemônica no Brasil e em outros países latinoamericanos, que legitimava as ditaduras civil-militares. Recordar a carta de Arrupe é ver como se faz um correto discernimento em um tempo tão conturbado quanto o da Guerra Fria, com seus aflitivos desdobramentos na América Latina. Também hoje não se deve desencorajar quem busca libertar os seres humanos de dominações e opressões, denunciar ideologias que ocultam a verdade e suprimir divisões sociais perversas. Continuam existindo formas de anticomunismo que não passam de meios para encobrir injustiças.

${ }^{41}$ LIBÂNIO, J. B., Nas pegadas de Medellín, as opções de Puebla. 
O Brasil vive uma onda política em que contestar discriminações e opressões feitas a índios, negros, mulheres e LGBT, é taxado como "coitadismo"; em que se quer rechaçar explicitamente o politicamente correto, dando lugar ao insulto, ao deboche e ao escárnio. Tudo em nome da pátria acima de tudo e de Deus acima de todos. A tradição católica, renovada pelo Concílio Vaticano II e pelas conferências episcopais, tem um importante papel profético a desempenhar. O primeiro papa latino-americano e jesuíta, Francisco, tem se revelado, como Arrupe, alguém muito atento aos sinais dos tempos e um profeta da renovação conciliar. Ele traz para o papado e para a Igreja, em nível universal, a vivência eclesial latino-americana com sua teologia e pastoral. As sementes de Medellín-Puebla e de Pedro Arrupe germinam e crescem.

\section{Referências bibliográficas}

ARENAS, S. Conferências do Conselho Episcopal latino-americano (CELAM). Theologica Latino-americana Enciclopédia Digital. Disponível em: $<$ http://theologicalatinoamericana.com/?p=1475>. Acesso em: 23 jan. 2019.

ARRUPE, P. Análise Marxista. Pergunte e Responderemos, n. 258, 1981. Disponível em: $\quad<$ http://www.fecomvirtudes.com.br/marxismo-analisemarxista-e-cristianismo-2/>. Acesso em: 25 jan. 2019.

CONCÍLIO VATICANO II. Constituição Pastoral Gaudium et Spes sobre a Igreja no mundo atual. Roma, 7 dez. 1965. Disponível em: $<$ http:// www.vatican.va/archive/hist_councils/ii_vatican_council/documents/vat-ii_ const_19651207_gaudium-et-spes_po.html >. Acesso em: 1 fev. 2019.

CELAM. Documento de Medellín: Presença da Igreja na Atual Transformação da América Latina à Luz do Concílio Vaticano II. Disponível em: < https://spirandiopadre.wordpress.com/documento-de-medellin-texto-integral/>. Acesso em: 31 jan. 2019.

CALVEZ. J.-Y. A análise marxista do capitalismo não caducou, afirma o jesuíta Jean-Yves Calvez. Entrevista em 25 out. 2006. IHU Online, n.300, 13 jul. 2009. Disponível em: <http://www.ihuonline.unisinos.br/index.php?option $=$ com_content $\& v i e w=$ article $\& i d=2679 \&$ secao $=300>$. Acesso em: 18 jan. 2010 . 
CELAM. Documento de Puebla: Conclusões da III $^{\mathrm{a}}$ Conferência Geral do Episcopado Latino-americano. Puebla de Los Angeles (México): Ed. Paulinas, 1979. Disponível em: <http://portal.pucminas.br/imagedb/documento/DOC_ DSC_NOME_ARQUI20130906182452.pdf>. Acesso em: 31 jan. 2109.

DE DONATIS, A.; TERRAMANI, M. Causa di beatificazione i canonizzazione del servo di Dio Pedro Arrupe Gondra, S.J. Eddito. Roma, 3 dez. 2018. Disponível em: <http://www.jesuitasbrasil.com/newportal/wp-content/ uploads/2019/01/versao-italiano.pdf $>$. Acesso em: 30 jan. 2019.

JOÃO PAULO I, PP. Primeira radiomensagem. L'Osservatore Romano, ed. port., 3 set. 1978. p. 6.

JOÃO PAULO II, PP. Sob o signo da fidelidade à luz do Concílio. L'Osservatore Romano, ed. port., 27 out. 1978. p. 1-2.

LEÃO XIII, PP. Lettre Encyclique Quod Apostolici Muneris. Roma, 1878. Disponível em : <http://w2.vatican.va/content/leo-xiii/fr/encyclicals/ documents/hf_1-xiii_enc_28121878_quod-apostolici-muneris.html $>$. Acesso em: 25 jun. 2019.

LIBÂNIO, J. B. Nas pegadas de Medellín: as opções de Puebla. Cadernos de Teologia Pública, v.5, n.37, 2008. Disponível em: <http://bit.ly/LxjeCW>. Acesso em: 28 jan. 2019.

LIBÂNIO, J. B. Nas pegadas de Medellín, as opções de Puebla. Entrevista a Bruna Quadros. IHU Online, n.264, 30 jun. 2008. Disponível em: $<$ http:// www.ihuonline.unisinos.br/index.php?option $=$ com_content\&view $=$ article\&id=1952\&secao=264>. Acesso em: 28 jan. 2019.

PAUlO VI, PP. Carta Encíclica Populorum Progressio. Roma, 1967. Disponível em: $\quad<$ http://w2.vatican.va/content/paul-vi/pt/encyclicals/ documents/hf_p-vi_enc_26031967_populorum.html>. Acesso em: 31 jan. 2019.

PAUlO VI, PP. Carta Apostólica Octogesima Adveniens. Roma, 1971. Disponível em: <http://w2.vatican.va/content/paul-vi/pt/apost_letters/ documents/hf_p-vi_apl_19710514_octogesima-adveniens.html >. Acesso em: 29 jan. 2019.

PAULO VI, PP. Omelia di Paolo VI. Roma, 29 jun. 1972. Disponível em: $<$ http://www.vatican.va/holy_father/paul_vi/homilies/1972/documents/hf_pvi_hom_19720629_it.html $>$. Acesso em: 25 jan. 2019. 
SOUZA, N. Do Rio de Janeiro (1955) à Aparecida (2007): um olhar sobre as Conferências Gerais do Episcopado da América Latina e do Caribe. Revista de Cultura Teológica, v.16, n.64, p. 127-146, jul./set. 2008.

\section{Luís Corrêa Lima}

Doutor em História pela Universidade de Brasília Docente do Departamento de Teologia da Pontifícia

Universidade Católica do Rio de Janeiro Rio de Janeiro / RJ - Brasil E-mail:1clima@puc-rio.br

Recebido: 04/02/19

Aprovado: 02/05/19 